$\begin{array}{ll}\text { Research Square } & \text { Preprints are preliminary reports that have not undergone peer review. } \\ \text { They should not be considered conclusive, used to inform clinical practice, } \\ \text { or referenced by the media as validated information. }\end{array}$

\title{
Glutathione S-transferase M1 and T1 Genes Deletion Polymorphisms and Blood Pressure Control Among Treated Essential Hypertensive Patients in Burkina Faso.
}

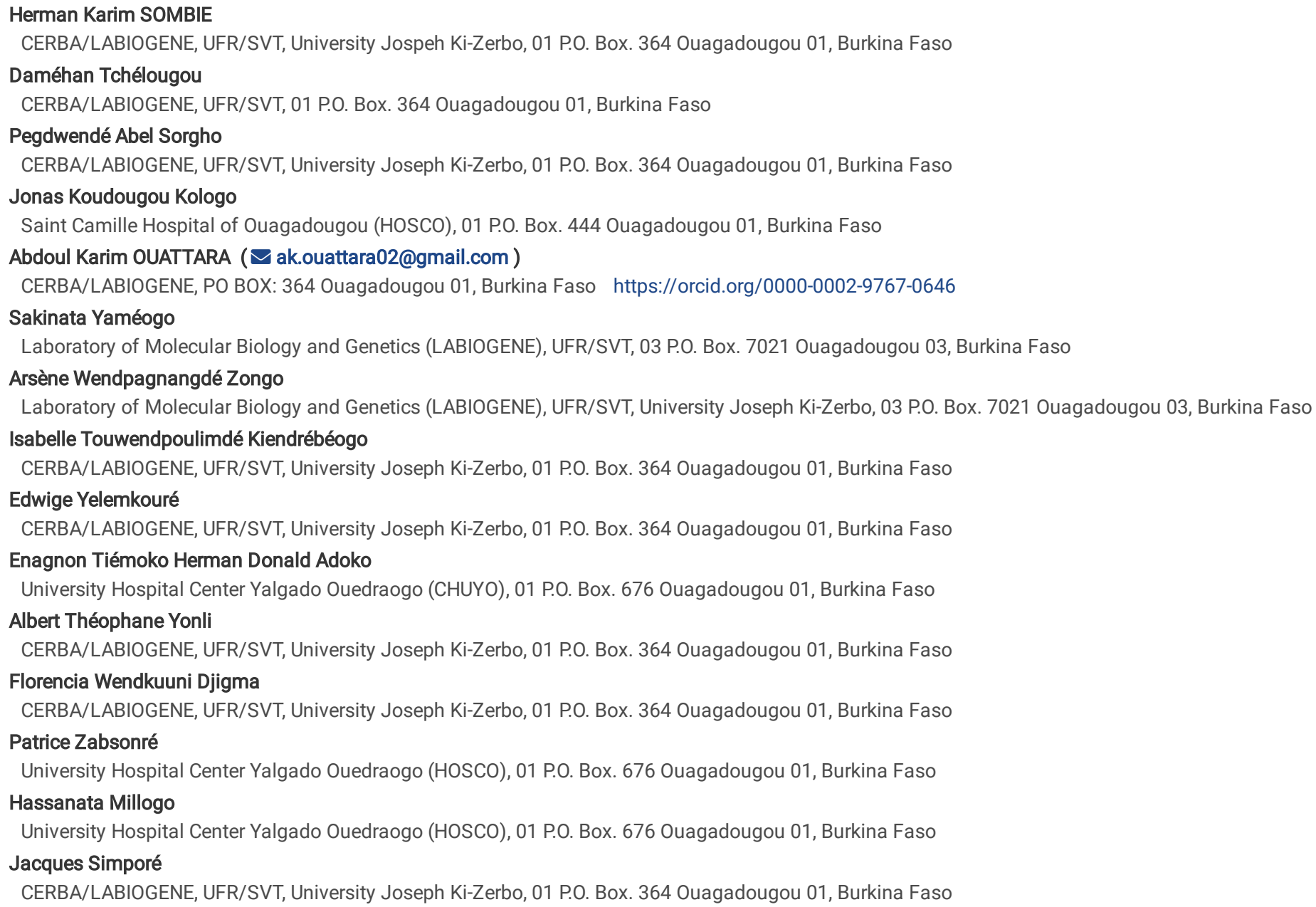




\section{Abstract}

Objective

Glutathione S-transferases have been associated with experimental resistance to some drugs. The present study investigated the factors associated with blood pressure control in patients with essential hypertension, especially the role of GSTT1 and GSTM1 genes polymorphisms. This cross-sectional study in Burkina Faso consisted of 200 patients with essential hypertension and under treatment.

Results

This cross-sectional study population consisted of $57.5 \%$ (115/200) of patients with their hypertension under control. No statistically significant difference ( $p$ $>0.05$ ) was found between controlled and uncontrolled (SBP and/or DBP) groups for anthropometric and biochemical parameters as well as for GSTT1 or GSTM1 gene polymorphisms. However, current alcohol consumption (OR = 3.04; $\mathrm{Cl}=1.88-6.13 ; p<0.001)$, physical inactivity $(\mathrm{OR}=3.07 ; \mathrm{Cl}=1.71-5.49 ; p<$ 0.001 ), severity of hypertension (Grade III [OR $=3.79 ; \mathrm{Cl}=2.00-7.17 ; p<0.001]$ ) and heart damage $(\mathrm{OR}=3,14 ; \mathrm{Cl}=1.59-6.02 ; p<0.001)$ were statistically more frequent in uncontrolled essential hypertension group than controlled group.

\section{Introduction}

Normalization of blood pressure (BP) in hypertensive patients significantly decreases the risk of stroke and heart disease and improves patients' quality of life [1].

However, the achievement rates of the BP target values (Systolic Blood Pressure $[\mathrm{SBP}]<140 \mathrm{mmHg}$ and Diastolic Blood Pressure [DBP] $<90 \mathrm{mmHg}$ ) remain low in the treated patients estimated at $37.1 \%$ worldwide in 2010 and less than $10 \%$ in Sub-Saharan Africa in 2013 [2, 3]. Black people are the more susceptible subgroup to hypertension and its complications [4], and are more exposed to uncontrolled hypertension or use of multiple drugs to control their BP [5]. It therefore becomes necessary to better understand the factors that affect control of hypertension in order to minimize their effects. Many studies have looked for factors associated with hypertension control but the contribution of genetic factors is less studied. Glutathione S-transferase (GST) plays a crucial role in the detoxification mechanisms of drugs and xenobiotics [6]. Studies in both humans and animals have shown that some polymorphisms that affect the expression of certain families of GST also affect the effectiveness of certain drugs [7-10]. These results suggest that GST could affect the bioavailability of certain drugs which acts as GST enzyme substrate. To date, no study to our knowledge has evaluated the link between GST and antihypertensive responses, although Glutathione S-transferases Mu1 deletion has been associated with resistant hypertension [11]. In this study we hypothesized that the active variants of Glutathione S-transferases Mu1 (GSTM1) and theta 1 (GSTT1) which have normal detoxification activity could reduce the bioavailability of certain antihypertensive drugs and therefore affect the control of BP in hypertensive patients.

Hence, we aim to determine the factors associated with blood pressure control among hypertensive patients in Burkina Faso, especially identify the contribution of GSTM1 and GSTT1 genes variants.

\section{Methods}

\subsection{Study design}

We conducted a cross-sectional study from July 15, 2017 to March 27, 2018, including 200 essential hypertensive patients followed in the cardiology department of Saint Camille Hospital of Ouagadougou (HOSCO), University Hospital Center Yalgado Ouédraogo (CHUYO) and the Medical Center of General Aboubacar Sangoulé Lamizana military Camp).

The study population consisted of subjects under antihypertensive treatments regardless of gender or social characteristics, aged from 18 to 70 years old.

Patients with secondary hypertension or no antihypertensive treatment, pregnant women and subjects not descendants from Burkina Faso were not included in this study.

Controlled blood pressure was defined as an average of SBP $<140 \mathrm{mmHg}$ and DBP $<90 \mathrm{mmHg}$ for all patients [12] during the last two consecutive medical visits under treatment.

\subsection{Samples and data collection}

A standardized questionnaire was used to collect socio-demographic, lifestyle, clinical and biological data (see questionnaire in additional file 3).

BP was measured using an electronic cuffed sphygmomanometer by cardiologist as described previously [15].

Body mass index (BMI) was used to classify patients as obese ( $\left.\geq 30 \mathrm{~kg} / \mathrm{m}^{2}\right)$, overweight $\left(25-30 \mathrm{~kg} / \mathrm{m}^{2}\right)$, normal weight $\left(20-25 \mathrm{~kg} / \mathrm{m}^{2}\right)$ and underweight $(\varangle 20$

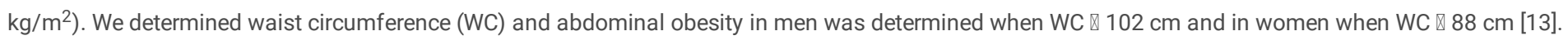
Family history of hypertension was determined in participants with at least one close family member being hypertensive before the age of 60 years. From each patient, venous blood sample was taken in EDTA tube and anticoagulant-free tube. Sera were directly used for biochemical analysis using CYANExpert 130 analyzer, and blood pellet were stored at $-20^{\circ} \mathrm{C}$ until DNA extraction.

\subsection{DNA extraction and genotyping}


The salting out method as described by Miller and al. in 1988 was used to isolate genomic DNA from peripheral white blood cells [14].

Genotyping of the GSTM1 and GSTT1 genes has been previously described [15]. Briefly we performed multiplex PCR with the GeneAmp PCR system 9700 (Applied Biosystem, USA) in a reaction volume of $25 \mu \mathrm{L}$ including $10 \mu \mathrm{L}$ of Master Mix AmpliTaq Gold® (Applied Biosystems, USA), $7 \mu \mathrm{L}$ of nuclease-free water, $5 \mu \mathrm{L}$ of DNA and $1 \mu \mathrm{L}$ of each primer pairs for each gene ( $\beta$-globin, GSTM1, GSTT1). After amplification, PCR products were migrated on ethidium bromidestained $3 \%$ agarose gel during $45 \mathrm{mn}$, bands were visualized under UV light at $312 \mathrm{~nm}$ using the Geneflash revelation device (Additional file1) and the generated data were interpreted as previously described [15].

\subsection{Statistical analysis}

We used Statistical Package for Social Sciences (20.0) and Epi Info (6.0) for data analyses. To determine sample size, we have taken into account following values: $95 \%$ of two-sided confidence level, $80 \%$ of power, odds ratio more than 2.2, ratio of controlled BP to uncontrolled BP 1.1, the proportion of controlled BP patients group having GSTM1-null and GSTT1-null about $50 \%$. We expressed quantitative variables and frequencies as mean \pm standard deviation and percentage respectively and comparisons between groups were done with t-test and chi-squared test respectively. Difference was considered as statistically significant when $p<0.05$.

\section{Results}

\subsection{Characteristics of the study population}

The table 1 presents the general characteristics of the study population. The BP levels of participants under treatment allowed us to classify them into patients with controlled and uncontrolled hypertension. We showed that 115 (57.5\%) had their BP under control.

Regarding the socio-demographic and biochemical data, there was no significant difference between the controlled and the uncontrolled group (all $p>0.05$ ).

Of the 200 patients under antihypertensive treatments, 99 patients were under monotherapy, 65 patients under bitherapy and 36 patients under Tritherapy (data not shown). Supplementary file 2.

\subsection{Influence of genetic variants of GSTM1 and GSTT1 on the control of blood pressure and essential hypertension.}

The table 2 presents and compares the frequencies of GSTM1 and GSTT1 variants between the controlled and uncontrolled SBP groups, between the controlled and uncontrolled DBP groups and between the controlled and uncontrolled hypertension group. We did not find any significant difference between those groups $(p>0.05)$.

\subsection{Research of non-genetic factors associated with the control of essential hypertension}

The Table 3 presents and compares the frequencies of non-genetic factors that have been associated with hypertension control in previous studies. Our results showed that alcohol consumption $(\mathrm{OR}=3.04 ; \mathrm{Cl}=1.88-6.13 ; p<0.001)$, physical inactivity $(\mathrm{OR}=3.07 ; \mathrm{Cl}=1.71-5.49 ; p<0.001)$, the severity of essential hypertension (Grade III [OR $=3.79 ; \mathrm{Cl}=2.00-7.17 ; p<0.001]$ ) and heart damage $(\mathrm{OR}=3,14 ; \mathrm{Cl}=1.59-6.02 ; p<0.001)$ were more frequent in uncontrolled essential hypertension group than controlled group and differences were significant.

\section{Discussion}

In this study, we investigate the factors associated with essential hypertension control in Burkina Faso. Our results showed that there was no significant difference between the controlled and the uncontrolled hypertension group by comparing the levels of biochemical parameters, suggesting that BP control is independent of blood glucose, cholesterol, triglycerides and creatinine levels.

In this study, there was no significant difference between the control rates of patients under monotherapy and bitherapy or tritherapy, unlike studies which have shown that monotherapy [16] or multi-drug therapy [17] was associated with the low control of hypertension.

However, we found that alcohol consumption, physical inactivity, the initial hypertension grade before medication and cardiac affections were associated with low control of essential hypertension. The influence of alcohol consumption on antihypertensive therapy has long been studied. Stewart et al., showed that the reduction of alcohol consumption increase the antihypertensive drugs effect and that the management of alcohol consumption must be considered as a major component of antihypertensive therapy in alcoholics [18]. Concerning physical exercise, a number of studies have consistently demonstrated its beneficial effects on hypertension with reductions in SBP and DBP of up to $5-7 \mathrm{mmHg}$ [19] and more frequent and long-term exercise leads to a more sustained reduction in BP, called exercise training response [20]. It is believed that the reduction in BP with physical activity is due to the attenuation of peripheral vascular resistance, which may be due to neurohormonal and structural responses [21]. Other mechanisms suggested in reducing BP through exercise include favorable changes in oxidative stress, inflammation, endothelial function, body mass, activity of the renin-angiotensin system, renal function, and insulin sensitivity [19]. Cardiac damages were found more in the uncontrolled group compared to the controlled group and this may be the cause or the effect of the poor control of blood pressure in essential hypertensive patients.

Our results also showed that there was no association between socio-demographic characteristics, residence areas and gender with BP control unlike other studies which have shown that women had a higher control rate than men in African countries [22]. Our results are similar to those reported in Tanzania by Maginga et al., who showed that age, gender, educational level, marital status, professional status and residency did not affect the control of hypertension 
[23]. However, unlike our study which found no association between obesity and the control of essential hypertension, that of Maginga et al., showed that it was associated with a poor control rate.

Considering the genetic aspects, we investigated the influence of variants of the GSTM1 and GSTT1 genes on the control of essential hypertension. Genetic factors may influence the pharmacokinetics and pharmacodynamics (tissue or organ responsiveness) of drugs [24]. Studies have reported that in cancer cells, GST often show high levels of expression when compared to normal cells [25] and this may contribute to increase detoxification of anticancer drugs [26]. It have been also shown that GST Through their detoxification activity, might play an important role in the protection against the toxic effect of the antimicrobial agents which leads bacteria to become resistant to antibiotics [27]

In HIV treated patients, homozygous deletion of GSTM1 and GSTT1 have been associated with CD4+ count rising above 350 cells/mm3 suggesting that patients with homozygous deletion have slower disease progression and better drug response [28]. Among GST genes, GSTM1 and GSTT1 are the most investigated in studies exploring genetic and drug response and they have been described as polymorphic in humans [29]. The most common polymorphisms of the loci of the GSTM1 and GSTT1 genes consist in the complete deletion of these genes (GSTM1-null and GSTT1-null) [30]. Individuals who are homozygous for the null genotype of GSTM1 or GSTT1 lack the respective enzyme functions [31, 32] and may have lower xenobiotic and drug detoxification activity than subjects with active genotypes.

In this study, our results showed that neither GSTM1 nor GSTT1 was associated with the control of essential hypertension; this at first sight indicates an absence of association between the active variants of these two genes and the low disponibility and efficacy of antihypertensive drugs. Some studies estimate that other members of the GST enzyme family must have compensated for the absence of a functional enzyme in the double deletion subjects [33, 34], which leads to the same level of activity of GST both in the null and active genotype. In addition to not confirming our initial hypothesis, our results may also not support the hypothesis that expression of the GSTM1 gene could protect against resistant hypertension [11].

\section{Conclusion}

In this study, the patient's lifestyle seems to be more determining in BP control under treatment than genetic factors studied. Especially alcohol consumption and physical inactivity are associated with a poor blood pressure control. In contrast, no association was found between GSTM1 and GSTT1 genes polymorphisms with systolic or diastolic blood pressure control in our study population. In addition, given the fact that an advanced disease stage, with or without cardiac complications, is also linked to a poor blood pressure control, an early diagnosis should be therefore encouraged for effective management and for better therapeutic responses.

\section{Limitations}

Our study could have certain limitations, in particular the small size of the study population and the lack of information on adherence to antihypertensive therapy. These observations could be taken into account in future studies.

\section{Abbreviations}

\begin{tabular}{lll} 
BMI & $:$ & Body mass index \\
\hline CERBA & $:$ & Pietro Annigoni Biomolecular Research Center \\
\hline DBP & $:$ & Diastolic blood pressure \\
\hline EDTA & $:$ & Ethylenediaminetetraacetic \\
\hline GSTM1 & $:$ & Glutathione S-transferases Mu 1 \\
\hline GSTT1 & $:$ & Glutathione S-transferasesTheta 1 \\
\hline HDL-C & $:$ & High-density lipoprotein cholesterol \\
\hline LABIOGENE & $:$ & Laboratory of molecular biology and genetics \\
\hline LDL-C & $:$ & Low-density lipoprotein cholesterol \\
\hline MD & $:$ & Means difference \\
\hline PCR & $:$ & Polymerase chain reaction \\
\hline ROS & $:$ & Reactive Oxygen Species \\
\hline SBP & $:$ & Systolic blood pressure \\
\hline SD & $:$ & Standard deviation \\
\hline SPSS & $:$ & Statistical Package for theSocial Sciences \\
\hline TC & $:$ & Total cholesterol \\
\hline WC & $:$ & waist circumference \\
\hline
\end{tabular}

\section{Declarations}




\section{Ethics approval and consent to participate}

The present study has been approved by the ethics committee of CERBA/LABIOGENE and the National Ethics Committee for Health Research of Burkina Faso.CERS20186065, 6 June 2018, retrospectively registered. Free and written consent was obtained from all participants of this study. The anonymity and confidentiality of the patients were respected as stated in the IRB (Institutional Review Board) protocol.

\section{Consent for publication}

Not Applicable

\section{Availability of data and materials}

The dataset generated in this study is available from NCBI Nucleotide under the accession number LC517160.1.

\section{Competing interests}

The authors declare that they have no competing interests

\section{Funding}

This work was supported by West African Economic and Monetary Union (WAEMU) through the "Programmed'appui et de développement des centresd'excellencerégionaux" (PACERII) and "Centre national de l'Information, de l'OrientationScolaire et Professionnelle, et des Bourses"(CIOSPB) especially for researcher life stipend. Financial support for reagents and consumables was provided by Italian Episcopal Conference (CEI).

The funding bodies played no role in the design of the study and collection, analysis, and interpretation of data and in writing the manuscript.

\section{Authors' contributions}

Study concept and design: SHK, JKK, TD, HM and JS. Sampling and Laboratory analysis: HKS, APS, SY, ITK, AWZ, EY, ETHDA and JKK. Statistical analysis and interpretation of data: HKS, APS, ATY, DT. Drafting of the manuscript: APS, HKS, TD, AKO and JS. Critical revision of the manuscript for important intellectual content: AKO, HKS, DT, FWD, HM, JKK, PZ and JS. Administrative, technical, and material support: FWD, ATY, JKK and JS. Study supervision: JKK, HM, PZ and JS.

The Corresponding Author declares that the manuscript has been read and approved by all named authors and that the order of authors listed in the manuscript has been approved by all of us.

\section{Acknowledgements}

The authors wish to thank all participants in this study. A deep gratitude to all the staff of Saint Camille Hospital of Ouagadougou (HOSCO) and Biomolecular Research Center Pietro Annigoni (CERBA) for technical support.

\section{References}

1. Park JY, Kim KA, Lee GS, Park PW, Kim SL, Lee YS, Lee YW, Shin EK: Randomized, open-label, two-period crossover comparison of the pharmacokinetic and pharmacodynamic properties of two amlodipine formulations in healthy adult male Korean subjects. Clinical therapeutics 2004, 26(5):715-723.

2. Ataklte F, Erqou S, Kaptoge S, Taye B, Echouffo-Tcheugui JB, Kengne AP: Burden of undiagnosed hypertension in sub-saharan Africa: a systematic review and meta-analysis. Hypertension 2015, 65(2):291-298.

3. Mills KT, Bundy JD, Kelly TN, Reed JE, Kearney PM, Reynolds K, Chen J, He J: Global Disparities of Hypertension Prevalence and Control: A Systematic Analysis of Population-based Studies from 90 Countries. Circulation 2016, 134(6):441-450.

4. Gu Q, Burt VL, Dillon CF, Yoon S: Trends in antihypertensive medication use and blood pressure control among United States adults with hypertension: the National Health And Nutrition Examination Survey, 2001 to 2010. Circulation 2012, 126(17):2105-2114.

5. Hajjar I, Kotchen TA: Trends in prevalence, awareness, treatment, and control of hypertension in the United States, 1988-2000. Jama 2003, 290(2):199206.

6. Hayes JD, Flanagan JU, Jowsey IR: Glutathione transferases. Annu Rev Pharmacol Toxicol 2005, 45:51-88.

7. Zhang Y, Yang L, Li R, Zhang L, Zhang MR, Xiao ZJ: [The effects of glutathione S-transferase (GSTT1 and GSTM1) genes polymorphisms on treatment efficacy and prognosis of acute myeloid leukemia]. Zhonghua nei ke za zhi 2006, 45(3):213-216.

8. Barahmani N, Carpentieri S, Li X-N, Wang T, Cao Y, Howe L, Kilburn L, Chintagumpala M, Lau C, Okcu MF: Glutathione S-transferase M1 and T1 polymorphisms may predict adverse effects after therapy in children with medulloblastoma. Neuro Oncol 2009, 11(3):292-300.

9. Kang Hw, Song PH, Ha Y-S, Kim WT, Kim Y-J, Yun S-J, Lee S-C, Choi YH, Moon S-K, Kim W-J: Glutathione S-transferase M1 and T1 polymorphisms: Susceptibility and outcomes in muscle invasive bladder cancer patients. European Journal of Cancer 2013, 49(14):3010-3019.

10. Ye H, Shao M, Shi X, Wu L, Xu B, Qu Q, Qu J: Predictive assessment in pharmacogenetics of Glutathione S-transferases genes on efficacy of platinumbased chemotherapy in non-small cell lung cancer patients. Scientific Reports 2017, 7(1):2670.

11. Cruz-Gonzalez I, Corral E, Sanchez-Ledesma M, Sanchez-Rodriguez A, Martin-Luengo C, Gonzalez-Sarmiento R: An association between resistant hypertension and the null GSTM1 genotype. Journal of human hypertension 2009, 23(8):556-558.

Page 5/10 
12. Kjeldsen S, Feldman RD, Lisheng L, Mourad JJ, Chiang CE, Zhang W, Wu Z, Li W, Williams B: Updated national and international hypertension guidelines: a review of current recommendations. Drugs 2014, 74(17):2033-2051.

13. Zhang C, Rexrode KM, van Dam RM, Li TY, Hu FB: Abdominal obesity and the risk of all-cause, cardiovascular, and cancer mortality: sixteen years of follow-up in US women. Circulation 2008, 117(13):1658-1667.

14. Miller SA, Dykes DD, Polesky HF: A simple salting out procedure for extracting DNA from human nucleated cells. Nucleic acids research $1988,16(3): 1215$.

15. Sombié HK, Sorgho AP, Kologo JK, OUATTARA AK, Yaméogo S, Yonli AT, Djigma FW, Tchelougou D, Somda D, Kiendrébéogo IT et al: Glutathione Stransferase $\mathrm{M} 1$ and $\mathrm{T} 1$ genes deletion polymorphisms and risk of developing essential hypertension: a case-control study in Burkina Faso population (West Africa). . BMC Medical Genetics 2020, 21:55.

16. Yameogo NV, Kagambega LJ, Millogo RC, Kologo KJ, Yameogo AA, Mandi GD, Ilboudo E, Toguyeni BJ, Samadoulougou AK, Zabsonre P: [Factors associated with poor blood pressure control in hypertensive black Africans: cross-sectional study of $\mathbf{4 5 6}$ hypertensive patients from Burkina Faso]. Ann Cardiol Angeiol (Paris) 2013, 62(1):38-42.

17. Barreto MdS, Matsuda LM, Marcon SS: Fatores associados ao inadequado controle pressórico em pacientes da atenção primária. Escola Anna Nery 2016, 20:114-120.

18. Stewart SH, Latham PK, Miller PM, Randall P, Anton RF: Blood pressure reduction during treatment for alcohol dependence: results from the Combining Medications and Behavioral Interventions for Alcoholism (COMBINE) study. Addiction 2008, 103(10):1622-1628.

19. Diaz KM, Shimbo D: Physical activity and the prevention of hypertension. Curr Hypertens Rep 2013, 15(6):659-668.

20. Pescatello LS: Exercise and hypertension: recent advances in exercise prescription. Curr Hypertens Rep 2005, 7(4):281-286.

21. Hamer M: The Anti-Hypertensive Effects of Exercise. Sports Medicine 2006, 36.

22. Kayima J, Wanyenze RK, Katamba A, Leontsini E, Nuwaha F: Hypertension awareness, treatment and control in Africa: a systematic review. BMC cardiovascular disorders 2013, 13:54.

23. Maginga J, Guerrero M, Koh E, Holm Hansen C, Shedafa R, Kalokola F, Smart LR, Peck RN: Hypertension Control and Its Correlates Among Adults Attending a Hypertension Clinic in Tanzania. J Clin Hypertens (Greenwich) 2016, 18(3):207-216.

24. Roden DM, George AL, Jr.: The genetic basis of variability in drug responses. Nature reviews Drug discovery 2002, 1(1):37-44.

25. Gate L, Tew KD: Glutathione S-transferases as emerging therapeutic targets. Expert opinion on therapeutic targets 2001, 5(4):477-489.

26. Sau A, Pellizzari Tregno F, Valentino F, Federici G, Caccuri AM: Glutathione transferases and development of new principles to overcome drug resistance. Archives of biochemistry and biophysics 2010, 500(2):116-122.

27. Pugazhendhi A, Dhanarani S, Shankar C, Prakash P, Ranganathan K, Saratale RG, Thamaraiselvi K: Electrophoretic pattern of glutathione S-transferase (GST) in antibiotic resistance Gram-positive bacteria from poultry litter. Microbial Pathogenesis 2017, 110:285-290.

28. Kuleape JA, Tagoe EA, Puplampu P, Bonney EY, Quaye O: Homozygous deletion of both GSTM1 and GSTT1 genes is associated with higher CD4+ T cell counts in Ghanaian HIV patients. PloS one 2018, 13(5):e0195954.

29. Ebeshi BU, Bolaji 00, Masimirembwa CM: Glutathione-S-transferase (M1 and T1) polymorphisms in Nigerian populations. J Med Genet Genomics 2011, 3(4):56-60.

30. Palma-Cano LE, Córdova EJ, Orozco L, Martínez-Hernández A, Cid M, Leal-Berumen I, Licón-Trillo A, Lechuga-Valles R, González-Ponce M, GonzálezRodríguez E et al: GSTT1 and GSTM1 null variants in Mestizo and Amerindian populations from northwestern Mexico and a literature review. Genetics and molecular biology 2017, 40(4):727-735.

31. Seidegard J, Vorachek WR, Pero RW, Pearson WR: Hereditary differences in the expression of the human glutathione transferase active on trans-stilbene oxide are due to a gene deletion. Proceedings of the National Academy of Sciences of the United States of America 1988, 85(19):7293-7297.

32. Pemble S, Schroeder KR, Spencer SR, Meyer DJ, Hallier E, Bolt HM, Ketterer B, Taylor JB: Human glutathione S-transferase theta (GSTT1): cDNA cloning and the characterization of a genetic polymorphism. The Biochemical journal 1994, 300 (Pt 1)(Pt 1):271-276.

33. Gronau S, Koenig-Greger D, Jerg M, Riechelmann H: Gene polymorphisms in detoxification enzymes as susceptibility factor for head and neck cancer? Otolaryngology-head and neck surgery : official journal of American Academy of Otolaryngology-Head and Neck Surgery 2003, 128(5):674-680.

34. Konig-Greger D, Riechelmann H, Wittich U, Gronau S: Genotype and phenotype of glutathione-S-transferase in patients with head and neck carcinoma. Otolaryngology-head and neck surgery : official journal of American Academy of Otolaryngology-Head and Neck Surgery 2004, 130(6):718-725.

\section{Tables}

Table 1: General characteristics of the study population according to hypertension control 


\begin{tabular}{|c|c|c|c|c|}
\hline Parameters & $\begin{array}{l}\text { Total } \\
n=200(100 \%)\end{array}$ & $\begin{array}{l}\text { Controlled HTA } \\
n=115(57.5 \%)\end{array}$ & $\begin{array}{l}\text { Uncontrolled HTA } \\
n=85(42.5 \%)\end{array}$ & $p$ value \\
\hline Gender (M/F) & $71 / 129$ & $40 / 75$ & $31 / 54$ & 0.88 \\
\hline Age (years) & $54.06 \pm 10.89$ & $54.16 \pm 11.1$ & $53.95 \pm 10.70$ & 0.89 \\
\hline SBP $(\mathrm{mmHg})$ & $137.54 \pm 16.84$ & $126.74 \pm 8.55$ & $150.61 \pm 15.06$ & $<0.001$ * \\
\hline DBP (mmHg) & $83.45 \pm 14.40$ & $78.77 \pm 8.27$ & $89.11 \pm 17.87$ & $<0.001$ * \\
\hline BMl $\left(\mathrm{Kg} / \mathrm{m}^{2}\right)$ & $28.76 \pm 6.38$ & $29.14 \pm 7.22$ & $28.39 \pm 5.32$ & 0.40 \\
\hline WC (cm) & $94.55 \pm 13.17$ & $94.17 \pm 13.26$ & $95.00 \pm 13.13$ & 0.66 \\
\hline Glucose (mM) & $5.44 \pm 0.96$ & $5.58 \pm 1.11$ & $5.41 \pm 1.01$ & 0.51 \\
\hline HDL-c (mM) & $1.56 \pm 0.93$ & $1.52 \pm 0.47$ & $1.61 \pm 1.27$ & 0.72 \\
\hline LDL-c (mM) & $2.98 \pm 1.00$ & $2.82 \pm 0.93$ & $3.15 \pm 1.05$ & 0.19 \\
\hline Total Cholesterol (mM) & $5.13 \pm 0.99$ & $4.88 \pm 0.98$ & $5.34 \pm 0.97$ & 0.1 \\
\hline Triglycerides (mM) & $1.26 \pm 0.94$ & $1.13 \pm 0.51$ & $1.39 \pm 1.23$ & 0.28 \\
\hline Creatine $(\mu \mathrm{M})$ & $111.52 \pm 94.42$ & $101.47 \pm 43.85$ & $121.57 \pm 126.48$ & 0.40 \\
\hline
\end{tabular}

Values are expressed as mean \pm standard deviation for continuous variables; the statistical analyzes were made by the $t$ test or the chi-square test; *: significant difference between the groups ( $p<0.05)$; SBP: systolic blood pressure; DBP: diastolic blood pressure; WC: waist circumference; HDL-c: high density lipoprotein cholesterol; LDL-c: low density lipoprotein cholesterol; mM: millimolar; $\mu M$ : micromolar.

Table 2: Distribution of GSTM1 and GSTT1 genes variants according to control state of essential hypertension, SBP and DBP 


\begin{tabular}{|c|c|c|c|c|c|c|c|c|c|}
\hline \multirow[t]{2}{*}{ Parameters } & \multirow[t]{2}{*}{ Genes -Variants } & \multicolumn{3}{|c|}{ SystolicBlood Pressure (SBP) } & \multicolumn{3}{|c|}{ Diastolic Blood Pressure (DBP) } & \multicolumn{2}{|c|}{ Hypertension } \\
\hline & & $\begin{array}{l}\text { Controlled } \\
\begin{array}{l}n=126 \\
(\%)\end{array}\end{array}$ & $\begin{array}{l}\text { Uncontrolled } \\
n=74(\%)\end{array}$ & $\begin{array}{l}p \\
\text { value }\end{array}$ & $\begin{array}{l}\text { controlled } \\
n=152 \\
(\%)\end{array}$ & $\begin{array}{l}\text { uncontrolled } \\
n=48(\%)\end{array}$ & $\begin{array}{l}p \\
\text { value }\end{array}$ & $\begin{array}{l}\text { Controlled } \\
n=115 \\
(\%)\end{array}$ & $\begin{array}{l}\text { Uncontrolled } \\
n=85 \text { (\%) }\end{array}$ \\
\hline \multirow{4}{*}{$\begin{array}{l}\text { Monotherapy } \\
n=110\end{array}$} & \# GSTM1-active & $\begin{array}{l}55 \\
(74.32)\end{array}$ & $30(83.33)$ & & $\begin{array}{l}66 \\
(76.74)\end{array}$ & $19(82.14)$ & & $\begin{array}{l}51 \\
(76.12)\end{array}$ & $34(79.07)$ \\
\hline & GSTM1-null & $\begin{array}{l}19 \\
(25.68)\end{array}$ & $6(16.77)$ & 0.34 & $\begin{array}{l}20 \\
(23.26)\end{array}$ & $5(17.86)$ & 1.00 & $\begin{array}{l}16 \\
(23.88)\end{array}$ & $9(20.93)$ \\
\hline & \# GSTT1-active & $\begin{array}{l}28 \\
(37.84)\end{array}$ & $10(27.78)$ & & $\begin{array}{l}31 \\
(36.05)\end{array}$ & $7(35.71)$ & & $\begin{array}{l}27 \\
(40.30)\end{array}$ & $11(25.58)$ \\
\hline & GSTT1-null & $\begin{array}{l}46 \\
(62.16)\end{array}$ & $26(72.22)$ & 0.39 & $\begin{array}{l}55 \\
(63.95)\end{array}$ & $17(64.29)$ & 0.63 & $\begin{array}{l}40 \\
(59.70)\end{array}$ & $32(74.42)$ \\
\hline \multirow{4}{*}{$\begin{array}{l}\text { Bitherapy } \\
n=55\end{array}$} & \# GSTM1-active & $\begin{array}{l}17 \\
(60.71)\end{array}$ & $17(70.83)$ & & $\begin{array}{l}24 \\
(61.54)\end{array}$ & $10(64.71)$ & & $\begin{array}{l}16 \\
(57.14)\end{array}$ & $18(66.67)$ \\
\hline & GSTM1-null & $\begin{array}{l}11 \\
(39.29)\end{array}$ & $7(29.17)$ & 0.56 & $\begin{array}{l}15 \\
(38.46)\end{array}$ & $6(35.29)$ & 1.00 & $\begin{array}{l}12 \\
(42.86)\end{array}$ & $9(33.33)$ \\
\hline & \# GSTT1-active & $\begin{array}{l}14 \\
(50.00)\end{array}$ & $9(37.50)$ & & $\begin{array}{l}16 \\
(41.03)\end{array}$ & $7(41.18)$ & & $\begin{array}{l}11 \\
(39.29)\end{array}$ & $12(44.44)$ \\
\hline & GSTT1-null & $\begin{array}{l}14 \\
(50.00)\end{array}$ & $15(62.50)$ & 0.41 & $\begin{array}{l}23 \\
(58.97)\end{array}$ & $9(58.82)$ & 1.00 & $\begin{array}{l}17 \\
(60.71)\end{array}$ & $15(55.56)$ \\
\hline \multirow{4}{*}{$\begin{array}{l}\text { Tritherapy } \\
n=35\end{array}$} & \# GSTM1-active & $\begin{array}{l}13 \\
(61.91)\end{array}$ & $9(64.28)$ & & $\begin{array}{l}19 \\
(70.37)\end{array}$ & $3(45.45)$ & & $\begin{array}{l}12 \\
(60.00)\end{array}$ & $10(66.67)$ \\
\hline & GSTM1-null & $8(38.09)$ & $5(35.72)$ & 1.00 & $8(29.63)$ & $5(54.55)$ & 0.11 & $8(40.00)$ & $5(33.33)$ \\
\hline & \# GSTT1-active & $7(33.33)$ & $8(57.14)$ & & $\begin{array}{l}10 \\
(37.04)\end{array}$ & $5(54.55)$ & & $7(35.00)$ & $8(53.33)$ \\
\hline & GSTT1-null & $\begin{array}{l}14 \\
(66.67)\end{array}$ & $6(42.86)$ & 0.18 & $\begin{array}{l}17 \\
(62.96)\end{array}$ & $3(45.45)$ & 0.24 & $\begin{array}{l}13 \\
(65.00)\end{array}$ & $7(46.67)$ \\
\hline \multirow{8}{*}{$\begin{array}{l}\text { Total } \\
n=\mathbf{2 0 0}\end{array}$} & \# GSTM1-active & $\begin{array}{l}85 \\
(67.46)\end{array}$ & $56(75.68)$ & & $\begin{array}{l}109 \\
(71.71)\end{array}$ & $32(69.64)$ & & $\begin{array}{l}79 \\
(68.70)\end{array}$ & $62(72.94)$ \\
\hline & GSTM1-null & $\begin{array}{l}41 \\
(32.54)\end{array}$ & $18(24.42)$ & 0.26 & $\begin{array}{l}43 \\
(28.29)\end{array}$ & $16(30.36)$ & 0.58 & $\begin{array}{l}36 \\
(31.30)\end{array}$ & $23(27.06)$ \\
\hline & \# GSTT1-active & $\begin{array}{l}49 \\
(38.89)\end{array}$ & 27 (36.49) & & $\begin{array}{l}57 \\
(37.50)\end{array}$ & $19(41.07)$ & & $\begin{array}{l}45 \\
(39.13)\end{array}$ & $31(36.47)$ \\
\hline & GSTT1-null & $\begin{array}{l}77 \\
(61.11)\end{array}$ & $47(63.51)$ & 0.76 & $\begin{array}{l}95 \\
(62.50)\end{array}$ & $29(58.93)$ & 0.86 & $\begin{array}{l}70 \\
(60.87)\end{array}$ & $54(63.53)$ \\
\hline & \#GSTM1(+)/GSTT1(+) & $\begin{array}{l}25 \\
(19.84)\end{array}$ & $16(21.62)$ & & $\begin{array}{l}34 \\
(24.34)\end{array}$ & $7(14.58)$ & & $\begin{array}{l}24 \\
(20.87)\end{array}$ & $17(20.00)$ \\
\hline & GSTM1(-)/GSTT1(+) & $\begin{array}{l}24 \\
(19.05)\end{array}$ & $11(14.87)$ & 0.63 & $\begin{array}{l}23 \\
(15.13)\end{array}$ & $12(25.00)$ & 0.11 & $\begin{array}{l}21 \\
(18.26)\end{array}$ & $14(16.47)$ \\
\hline & GSTM1(+)/GSTT1(-) & $\begin{array}{l}60 \\
(47.62)\end{array}$ & $40(54.05)$ & 1.00 & $\begin{array}{l}75 \\
(49.34)\end{array}$ & $25(52.08)$ & 0.37 & $\begin{array}{l}55 \\
(47.83)\end{array}$ & $45(52.94)$ \\
\hline & GSTM1(-)/GSTT1(-) & $\begin{array}{l}17 \\
(13.49)\end{array}$ & $7(9.46)$ & 0.59 & $\begin{array}{l}20 \\
(13.16)\end{array}$ & $4(8.33)$ & 1.00 & $\begin{array}{l}15 \\
(13.04)\end{array}$ & $9(10.59)$ \\
\hline
\end{tabular}

Values are expressed in numbers (percentages) and the comparison between groups was made using the chi-square test; *: significant difference between the groups ( $p$ <0.05); \#: reference; (+): active; (-): null. 


\begin{tabular}{|c|c|c|c|c|c|}
\hline Parameters & $\begin{array}{l}\text { Controlled } \\
n=115(\%)\end{array}$ & $\begin{array}{l}\text { Uncontrolled } \\
n=85(\%)\end{array}$ & OR & $\mathrm{Cl}$ & $p$ value \\
\hline \multicolumn{6}{|l|}{ Sex } \\
\hline Men/Women & $40 / 75$ & $31 / 54$ & 0.92 & $0.51-1.16$ & 0.88 \\
\hline \multicolumn{6}{|l|}{ Age } \\
\hline$\leq 45$ years & $22(19 \%)$ & $21(25 \%)$ & 1.38 & $0.70-2.73$ & 0.38 \\
\hline 46 - 55 years & $44(38 \%)$ & $31(36 \%)$ & 0.92 & $0.51-1.65$ & 0.88 \\
\hline 56 - 65 years & $28(24 \%)$ & $25(30 \%)$ & 1.29 & $0.68-2.43$ & 0.42 \\
\hline$\geq 66$ years & $21(18 \%)$ & $8(9 \%)$ & 0.46 & $0.19-1.10$ & 0.10 \\
\hline \multicolumn{6}{|l|}{ Residence } \\
\hline Rural/ Urban & $31 / 84$ & $15 / 70$ & 1.72 & $0.86-3.44$ & 0.13 \\
\hline \multicolumn{6}{|l|}{ Behavioral factors } \\
\hline Current alcohol use & $34(30 \%)$ & $50(59 \%)$ & 3.04 & $1.88-6.13$ & $<0.001^{\star}$ \\
\hline Current tobacco use & $10(8.6 \%)$ & $7(8 \%)$ & 0.94 & $0.34-2.58$ & 1 \\
\hline Low sodium diet & $6(5.2 \%)$ & $7(8 \%)$ & 1.63 & $0.52-5.03$ & 0.40 \\
\hline Lack of physical exercise & $39(34 \%)$ & $52(61 \%)$ & 3.07 & $1.71-5.49$ & $<0.001^{\star}$ \\
\hline Normal weight & $35(30 \%)$ & $23(27 \%)$ & 0.84 & $0.45-1.57$ & 0.63 \\
\hline Overweight and obesity & $80(70 \%)$ & $62(73 \%)$ & 1.17 & $0.63-2.19$ & 0.63 \\
\hline Central obesity & $60(52 \%)$ & $48(56 \%)$ & 0.84 & $0.48-1.48$ & 0.56 \\
\hline \multicolumn{6}{|l|}{ Grade hypertension } \\
\hline Grade I & $44(39 \%)$ & $14(16 \%)$ & 0.31 & $0.16-0.63$ & $<0.001^{*}$ \\
\hline Grade II & $50(43 \%)$ & $32(38 \%)$ & 0.78 & $0.44-1.39$ & 0.46 \\
\hline Grade III & $21(18 \%)$ & $39(46 \%)$ & 3.79 & $2.00-7.17$ & $<0.001^{\star}$ \\
\hline \multicolumn{6}{|l|}{ Personal history } \\
\hline Heart involvement Yes/No & $17 / 98$ & $30 / 55$ & 3.14 & $1.59-6.02$ & $<0.001^{\star}$ \\
\hline Diabetes mellitus Yes/No & $14 / 101$ & $7 / 78$ & 0.64 & $0.24-1.68$ & 0.48 \\
\hline Asthma Yes/No & $3 / 112$ & $3 / 82$ & 1.36 & $0.26-6.93$ & 0.70 \\
\hline Taste Yes/No & $6 / 109$ & $6 / 79$ & 1.37 & $0.42-4.43$ & 0.76 \\
\hline \multicolumn{6}{|l|}{ Family history } \\
\hline Hypertension Yes/No & $70 / 45$ & $56 / 29$ & 1.24 & $0.69-2.22$ & 0.55 \\
\hline Diabetes mellitus Yes/No & $70 / 45$ & $56 / 29$ & 1.24 & $0.69-2.22$ & 0.55 \\
\hline \multicolumn{6}{|l|}{ Treatment level } \\
\hline Monotherapy & $59(51 \%)$ & $40(47 \%)$ & 0.90 & $0.51-1.58$ & 0.77 \\
\hline Bitherapy & $35(31 \%)$ & $30(35 \%)$ & 1.21 & $0.67-2.18$ & 0.54 \\
\hline Tritherapy & $21(18 \%)$ & $15(18 \%)$ & 0.88 & $0.41-1.85$ & 0.85 \\
\hline \multicolumn{6}{|l|}{ Professional status } \\
\hline Household & $45(40 \%)$ & $24(32 \%)$ & 0.61 & $0.33-1.11$ & 0.13 \\
\hline Farmer & $5(4 \%)$ & $2(2 \%)$ & 0.53 & $0.10-2.80$ & 0.70 \\
\hline Official & $24(21 \%)$ & $24(32 \%)$ & 1.49 & $0.77-2.86$ & 0.24 \\
\hline Daily & $1(1)$ & $1(1 \%)$ & 1.35 & $0.10-22.01$ & 1 \\
\hline Unemployed & $6(5 \%)$ & $5(7 \%)$ & 1.13 & $0.33-3.85$ & 1 \\
\hline Retirement & $9(8 \%)$ & $7(9 \%)$ & 1.05 & $0.37-2.96$ & 1 \\
\hline trader & $20(17 \%)$ & $14(21 \%)$ & 1.09 & $0.51-2.3$ & 0.84 \\
\hline Other & $5(4 \%)$ & $8(13 \%)$ & 2.28 & $0.72-7.25$ & 0.24 \\
\hline
\end{tabular}


Values are expressed in numbers (percentages) and the comparison between groups was made using the chi-square test; *: significant difference between the groups $(p<0.05)$.

\section{Supplementary Files}

This is a list of supplementary files associated with this preprint. Click to download.

- renamed63146.docx

- renamed80cce.docx

- renamed33501.docx 